UDC 372.881.111.1

\title{
Lobachova Iryna
}

Candidate of Philological Sciences, Associate Professor Primary Education Theory and Practice Department State University "Donbas State Pedagogical University" Sloviansk, Ukraine

sbitneva.irina@ukr.net

\section{IMPLEMENTING WIMMELBUCH AT ENGLISH LESSONS IN THE CONTEXT OF FORMING THE NEW UKRAINIAN SCHOOL}

\begin{abstract}
The article is devoted to the problem of improving the English teaching system at primary school in the context of the formation of the New Ukrainian School, which gives students not only knowledge but also the ability to use it in their life. Students master knowledge and skills through activities and acquire competencies. The aim of the paper is to perform the theoretical and practical study of the problem of implementing a Wimmelbuch at English lessons in primary school in the context of forming the New Ukrainian School. The outlined aim includes the following tasks: to outline the main advantages of using the Wimmelbuch teaching English at primary school and to propose language exercises for practicing in English using the Wimmelbuch on the initial level of studying a foreign language. To achieve this aim and to solve these tasks the following methods of research such as analysis, synthesis, systematization and generalizations are used. These methods helped to get into the essence of the outlined problem, to pass logically from less general idea (concept) to another that is more general. The New Ukrainian School is aimed at educating a harmoniously developed and socially active person, innovator and a citizen who is able to make responsible decisions, to solve the most difficult issues of society, to adhere to human rights and freely break language barriers in intercultural communication. So, nowadays all English lessons must be organized for creating conditions for communication: to make up monologues, dialogues, and polylogues by students on different themes and purposes. The illustrative material of the Wimmelbuch is subordinated to this aim. The interactive exercises offered in this article help students to learn how to express their thoughts correctly, consistently, exactly and expressively. They encourage students to make direct utterances (creating their own texts) and to make up stories thinking their own beginnings and finals of them. It is found out that in organizing such communication and teaching much attention is given to the development of skills of the speech culture and as the result it is noticed improving the speech culture of students and forming skills in communicative activity in any area of life.
\end{abstract}

Key words: Wimmelbuch, speech culture, language barrier, intercultural communication, New Ukrainian School, Primary Education Reform.

Introduction. The new Law of Ukraine "On Education" (2017) regulates the basic principles of a new educational system - the New Ukrainian School, in which it is pleasant to study and it gives to students not only knowledge but also the ability to use it in their life. Students master knowledge and skills through activity and acquire competences. The New Ukrainian School is aimed at educating an innovator and a citizen who is able to make responsible decisions, adheres to human rights and freely breaks language barriers in intercultural communication. Teaching at the New Ukrainian School opens a free field for activities and experiments to a modern teacher [1].

Literature review. The statements of the New Ukrainian School are substantiated in the new Law "On Education" (2017). The research of the specifics of the communicative phenomena is engaged by such scholars as M. Bovtenko, V. Demyankov, Yu. Karaulov, and others. The problem of forming foreign language communicative competence is considered by O. Vasylyev, H. Lytvynenko, L. Nevirko, and others. The issues of training future teachers of foreign languages have been examined by such researchers as O. Bihych, L. Byrkun, I. Mamchur, and others. The problem of improving the teaching of foreign languages at primary school is considered by $\mathrm{O}$. Kolominova, S. Nikolayeva, V. Plakhotnyk, and others. The issue of using such kind of the visual means as the Wimmelbuch at English lessons in primary school in the context of Primary Education Reform is required the detailed analysis. It determines the relevance of the outlined problem.

The aim of the paper is to perform the theoretical and practical study of the problem of implementing the Wimmelbuch at English lessons in primary school in the context of forming the New Ukrainian School. The tasks of the research are to outline the main advantages of using the Wimmelbuch teaching English at primary school and to propose language tasks for practicing in
English using the Wimmelbuch.

Methods of the research. Taking into account the specifics of the tasks such methods as analysis, synthesis, systematization and generalizations are used in the scientific research. It allowed to make full conclusions, to get into the essence of the outlined problem and to pass logically from the general idea to the main one.

Discussion. For teaching in a new way, a teacher must be given the freedom to act - to choose teaching materials, to improvise and experiment. This freedom is given by the new law "On Education". The New Ukrainian School is a dynamic combination of knowledge, skills, abilities, ways of thinking, points of views, values, and other personal qualities, which determines the ability of a person to socialize successfully, conduct professional and/or further educational activity. So, the core of knowledge is formed, on which abilities to use this knowledge will be supplemented, and values and skills that will be needed by graduates of the Ukrainian school in professional and private life.

Thus, the common competencies are so-called crosscutting skills: comprehensive reading, the ability to express one's opinion in oral and written forms, critical and systematic thinking, the ability to justify a position logically, creativity, initiative, the ability to manage emotions constructively, to evaluate risks, to make decisions, to solve problems, the ability to co-operate with other people [1]. The ability to express one's opinion in oral and written forms concerns not only the native language, but also a foreign one (English). It is also important for students to acquire foreign language communication skills and abilities to use them in real situations of communication.

Problems of speech development of primary students should be solved on the basis that speech functions and develops in an inextricable unity with substantively productive types of activity (labor, research, artistic, game, etc), which determine the motives and the content of communication. The most important changes in 
speech are related to the educational activity of students in primary school.

So, for the effective formation and further development of communication skills of primary students at English lessons it is necessary to create didactic conditions for their successful foreign language training. It is considered to implement the Wimmelbuch into the educational process of primary students to interest in learning a foreign language and using it in life communication situations. Implementing the Wimmelbuch at English lessons gives wide opportunities for activating teaching. The Wimmelbuch is the visual means belonging to the group of active methods of teaching practical English [2].

Plot illustrations of Wimmelbuch are the conditional reproduction of the real practical activity of people and creates conditions for real communication. The effectiveness of teaching here is primarily due to the explosion of motivation, increase the personal interest in learning English.

The Wimmelbuch motivates language activity because students who are studied are in a situation where the need to say something, ask, find out, prove, and share something with a partner is actualized. Primary students are clearly convinced that the language can be used as a means of communication. It activates the students' desire for contact with each other and a teacher, creates conditions for equality in the language partnership, destroys the traditional language barrier [4]. In such created situations students master the following elements of communication: the ability to begin a conversation, support it, interrupt an interlocutor, agree or disprove with one's opinion at the right time; the ability to listen to an interlocutor consciously, to ask clarifying questions, etc.

Almost all the educational time of such activity is for language practice, while both a speaker and a listener are as active as possible, because he/she has to understand and memorize the replica of partner, to correlate it with the situation, to determine how it is relevant to the situation and the task of communication, and to react properly.

For example, at the beginning of the book "Day at the Zoo" there is an instruction how to use it and tasks for the search strategy. In addition, at each page there is the zoo at a different time of a day. The activity of the participants, workers and visitors of the zoo (or their absence) is determined by the time of a day. There is the task at each page - to find a character or a thing, and also we always have to remember about the main task that is given at the beginning of the book. In this book we can see that a day at the zoo starts early in the morning, still dark, with feeding the animals and cleaning up, kiosks are opened, visitors come, an elephant is brought, a monkey has run away, a thunderstorm has begun and all visitors run, the zoo is closed in the evening, the animals have a rest, etc. It is also possible to watch with the interest the caretaker of the zoo, cute monkeys-gibbons, a pickpocket, etc. So, the usual story about the work of the zoo is told in the book; this book prompts to search and disclose secrets, forcing to look for participants of the book among the great number of small figures and elements of the picture [3].

The basic statements of using the Wimmelbuch at English lessons are to create favourable conditions for mastering oral speech; to provide personally oriented education; to create emotional and positive relationships between a teacher and students; to focus on oral speech communication.

The main aim in teaching English using the Wimmelbuch is forming students' needs in speech activity, because learning has the activity feature: students try to solve real and imaginary problems.

So, in order to work effectively with the illustrative material of the Wimmelbuch, we offer the following language exercises (games) that will help to form the foreign language communication skills.

\section{Cute animals in the Zoo.}

1. Someone starts the game by saying: e.g. I went to the zoo and I saw a big tiger...

2. The next person has to think of an animal that starts with the last letter of the animal that's been said (e.g. tiger ... rhino!).

3. They repeat the sentence, adding their animal (e.g. I went to the zoo and I saw a rhino...).

4. Everyone takes turns adding a new animal, without repeating any (e.g. I went to the zoo and I saw an ostrich...).

5 . The game continues until someone can't think of an animal that follows on from the last one.

\section{Group a story.}

In this game, everyone contributes to a story, one sentence at a time. Try to make each sentence easy to follow with another one.

1. Someone starts by making up a sentence. It can be long or short (e.g. As a girl waded through the crowd, she looked up and saw a giraffe...).

2. Someone else adds another sentence (e.g. It was a very tall spotted giraffe)

3. Everyone takes turns adding a new sentence: (e.g. a) She took the cookies and gave it to the giraffe; b) The giraffe did not take the cookies; 3) So, she decided to feed the monkeys, etc.).

4. The student who ends the story starts a new one.

\section{Eat the alphabet.}

In this game, everyone adds to a list of foods in the order of the alphabet. Agree which letters are too hard (such as Q, X or Z) and leave them out.

1. Someone says that they're going to eat a kind of food that starts with an A (e.g. I'm hungry! I'm going to eat an apple, etc.).

2. The next person repeats the first part of the sentence, then adds a food beginning with B (e.g. I'm hungry! I'm going to eat a banana).

3 . Someone else adds a food beginning with $\mathrm{C}$, and the game continues with everyone taking turns (e.g. I'm hungry! I'm going to eat cheese, a date, an egg, ... a kiwi fruit, a peach...).

4. If anyone can't think of a food that begins with the next letter, they're out.

\section{What's the noise?}

1. Someone thinks of a noise to make. It could be: a dog barking, a horse neighing, a phone ringing, a police siren, water noise..

2. They make the noise to someone else, using their mouth or hands (e.g. If you're in the Zoo, don't make sudden noises that will distract animals. To make the sound of a police siren, make a "whoo-whoo" noise with your mouth. For a horse galloping, you could clap your hands to make the sound of pounding hooves).

3 . The other person tries to guess what the noise is (Hmm... Is it a heart beating?).

4. If they are correct, they make the next noise. If not, they can continue guessing. If they decide to give up guessing, the first person can make another noise.

\section{Endless questions.}

In this game, two students talk to each other and can only ask questions. Ask someone else to be a referee.

1. One person starts by asking a question (e.g. Why do ducks quack?).

2 . The other person replies with a question that follows on logically from the first one, as quickly as they can (e.g. Do you think they should bark instead?).

3 . They take turns, and the referee listens closely. If anyone hesitates for too long or gives an answer that isn't a question, the referee tells them that they're out (e.g. $1^{\text {st }}$ Student: Shouldn't barking be left to dogs? $2^{\text {nd }}$ Student: ...Um... Er... Um... Referee: Sorry, you're out!). No one can argue with the referee.

4. Whoever is out first is the referee in the next game. 
6. Animal circles.

To play this game, each person needs a piece of paper and some pencils or pens.

1. Everyone draws a large circle for a body and fills it in. They add a circle for the head...

2. ... and four small circles for feet.

3. Everyone passes their paper to someone else, then they all use a pen to make the circles into animals (e.g. For a tall giraffe draw the head and feet a long way from the body. You can draw two feet so the circles become a bird. Add pointed ears, a tail and whiskers for a cat).

\section{Still as an animal.}

1. Choose someone to be a statue of an animal. The statue can stand or sit, and has to stay completely still (e.g. Making faces like a monkey, swimming like a fish, running like a lion, climbing like a bear...).

2. Everyone else tries to make the statue move. They're not allowed to touch her, but they can try.

3. When the statue moves, smiles or laughs, you have to guess the figure of an animal. And it's someone else's turn to be the statue.

\section{Walk like an animal.}

1. Everyone thinks of something that they're going to walk like. They don't tell the others what it is: a penguin, a duck, a bear, a monkey, a turtle, an ostrich etc.

2. Then everyone walks around in the style of whatever they've thought of.

3. Everyone tries to guess what the others are walking like (Are you a duck? Are you a monkey?).

4. If someone's walk is guessed correctly, they are out, and stop walking around. Students can only guess while they are playing. The winner is the last person walking.

\section{Who am I?}

1. To start, someone thinks of a character on the picture, for the others to guess... (e.g. a policeman, a doctor, an ice cream seller, a cleaner, a boy with a balloon, etc.).

2 . They give a clue about the character, and everyone else has one guess each (e.g. I'm near a cage with lions who am I? I'm next to a cage with monkeys who am I? I'm on the bridge who am I?).

3 . If someone is correct, they think of a new character for the others to guess. If no one guesses correctly, they are given another clue.

4. Continue playing until someone guesses who the character is, then play again.

\section{Funny animals.}

Each student needs paper, and a pen or pencil.

1. Fold each piece of the paper in half, then unfold it again.

2. Draw the top half of an animal on the top half of the paper. Draw lines going over the fold a little, too.

3. Fold back the top half of the paper to hide the drawing. Then, pass the paper to someone else.

4. Draw the bottom half of an animal, then unfold each piece of the paper to reveal an animal.

\section{Moo... Baa!}

To play this game, make a circle facing each other.

1. Each student chooses an animal noise, then makes the noise, so that the others can hear how it sounds: Baa! Meow! Moo! Woof! Quack! To whit to whoooo! Tweet! Oink! Squeak! Neigh! Thump! Hiss! Cluck! Ribbit! Buzz! Haw hee haw! Pawoooo! Growls-grrr-grrr! Roars!
Everyone needs to make a different noise.

2. To start, one student makes their noise, then makes someone else's, too (e.g. Moo... Baa! Moo... Woof! Woof... Hiss! etc.).

3 . That student then makes their own noise, followed by another student's noise.

4. The game continues with each player making their own noise, followed by someone else's: Woof... Cluck! Cluck... Buzz! Buzz... Moo! Moo... Baa! So, you can make the noise of the student who just chose you.

5 . If anyone makes the wrong noise, or makes the noises in the wrong order, they are out.

\section{Shape drawings.}

For this drawing game, you'll need some paper and pens or pencils.

1. Someone chooses a shape such as: a circle, a triangle, a square, an egg, an oval, a diamond, a rectangle.

2 . Someone else thinks of a subject for everyone to draw. It can be absolutely anything such as: a dog, a fish, a pig, a giraffe, a cat, a tortoise, etc.

3. Everyone draws the subject, using only the shape that's been chosen (e.g. A dog drawn using squares; a fish drawn using triangles; a sheep drawn using ovals, etc.).

\section{Story-telling game.}

In this imagination game, everyone adds to a story, five words at a time.

1. Someone starts by making up the first five words of the story (e.g. Suddenly, the door of a cage...).

2. Someone else adds another five words (e.g. creaked open and a big lion..., put its head through the door...).

3 . Everyone takes turns to add five words.

4. Make sure that the story makes sense.

5. When everyone wants to stop playing, someone has to think of a good way to end the story.

Such language exercises (games) help students to learn expressing their thoughts correctly, consistently, exactly and expressively. They encourage students to make direct utterances (creating their own texts) and to make up stories thinking their own beginnings and finals of them. Besides organizing such communication and teaching much attention is given to the development of the skills of the speech culture such as not to interfere adults in their conversation, not to interrupt a friend, not to lower a head in a conversation, to look into the eyes of the partner, to listen quietly to the narrator, prevent the rough tone, not to gesticulate, etc. Thus, we assure that such activity helps to improve students' speech culture and to form skills in communication in any area of life.

Conclusions. The New Ukrainian School is aimed at educating a harmoniously developed and socially active person who is able to solve the most difficult problems of society at present time of its development. Nowadays all English lessons must be organized for creating conditions for communication: to make up monologues, dialogues, and polylogues by students on different themes and purposes. The illustrative material of the Wimmelbuch is subordinated to this aim. Implementing such books into the educational process of primary school gets positive effect on forming students' cognitive activity, foreign language communication skills, and promotes conscious learning English. In further articles it is planned to offer exercises for the development of foreign language skills in speaking using the Wimmelbuch of the series "My favourite food".

\section{References}

1. Nova ukrainska shkola [New Ukrainian School]. Retrieved from https://mon.gov.ua/ua/tag/nova-ukrainska-shkola [in Ukrainian].

2. Lobachova, I. (2017). Pedagogical Conditions of Using a Wimmelbuch at English Lessons at Primary School. Profesionalizm pedahoha: teoretychni y metodychni aspekty [Professionalism of the teacher: theoretical and methodical aspects], 5 (2), 246255. Retrieved from http://pptma.dn.ua/index.php/uk/ [in English].

3. Wimmelbilderbuch. Retrieved from https://de.wikipedia.org/wiki/Wimmelbilderbuch [in German].

4. Wimmelbuch Club. Retrieved from http://wimmelbuch.club/ [in Russian]. 


\title{
Список використаної літератури
}

1. Нова українська школа [Електронний ресурс]. - URL: https://mon.gov.ua/ua/tag/nova-ukrainska-shkola

2. Lobachova I. Pedagogical Conditions of Using a Wimmelbuch at English Lessons at Primary School / Iryna Lobachova // Професіоналізм педагога : теоретичні й методичні аспекти : [наукове електронне видання]. - Вип. 5. - Ч.2. - 2017. Режим доступу : http://pptma.dn.ua/index.php/uk/

3. Wimmelbilderbuch [Електронний ресурc]. - URL : https://de.wikipedia.org/wiki/Wimmelbilderbuch

4. Wimmelbuch Club [Електронний ресурc]. - URL : http://wimmelbuch.club/

Стаття надійшла до редакції 07.04.2018 р. Стаття прийнята до друку 11.04.2018 р.

\section{Лобачова Ирина}

кандидат филологических наук, доцент

кафедра теории и практики начального образования

ГВУЗ «Донбасский государственный педагогический университет»

г. Славянск, Украина

\section{ИМПЛЕМЕНТАЦИЯ ВИММЕЛЬБУХОВ НА УРОКАХ АНГЛИЙСКОГО ЯЗЫКА В КОНТЕКСТЕ ФОРМИРОВАНИЯ НОВОЙ УКРАИНСКОЙ ШКОЛЫ}

Аннотация. Статья посвящена проблеме усовершенствования системы обучения иностранному языку в начальной школе в контексте формирования Новой украинской школы. Целью статьи является теоретикопрактическое исследование вопроса имплементации виммельбухов на начальном уровне изучения английского языка в Новой украинской школе. Предусмотрено выполнение таких заданий: определить главные преимущества использования виммельбухов при изучении английского языка в начальной школе; предложить языковые задания для работы с виммельбухами на начальном уровне изучения английского языка. В статье использованы такие методы исследования, как анализ, синтез, систематизация, обобщение, которые помогли проникнуть в суть обозначенной проблемы. Выяснено, что Новая украинская школа призвана воспитать всесторонне развитую, социально активную личность, которая умеет принимать ответственные решения, соблюдает права человека и свободно преодолевает языковые барьеры в межкультурной коммуникации. Для этого современные уроки английского языка необходимо структурировать так, чтобы они создавали условия для общения (составление учащимися монологов, диалогов, полилогов на разные темы с различными целями). Этой цели и соответствует иллюстративный материал виммельбухов. В статье предложены языковые упражнения, которые помогают ученикам научиться выражать свои мысли правильно, последовательно, точно и выразительно; побуждают учеников к непосредственным высказываниям и составлению рассказов, придумыванию своего начала и конца истории. Кроме этого, при организации такого общения и обучения значительное внимание уделено развитию навыков культуры речи, что способствует повышению речевой культуры учащихся и формированию у них навыков коммуникативной деятельности в любой сфере жизни.

Ключевые слова: виммельбух, культура речи, языковой барьер, межкультурная коммуникация, Новая украинская школа, реформа начального образования.

\author{
Лобачова Ірина Миколаївна \\ кандидат філологічних наук, доцент \\ кафедри теорії і практики початкової освіти \\ ДВНЗ «Донбаський державний педагогічний університет» \\ м. Слов'янськ, Україна
}

\section{ІМПЛЕМЕНТАЦІЯ ВІММЕЛЬБУХІВ НА УРОКАХ АНГЛІЙСЬКОЇ МОВИ В КОНТЕКСТІ ФОРМУВАННЯ \\ НОВОї УКРАЇНСЬКОї ШКОЛИ}

Анотація. Статтю присвячено проблемі вдосконалення системи навчання іноземної мови в початковій школі в контексті формування Нової української школи. Метою розвідки визначено теоретико-практичне дослідження питання імплементації віммельбухів на початковому ступені вивчення англійської мови в Новій українській школі. Окреслено виконання таких завдань: визначити головні переваги використання віммельбухів під час вивчення англійської мови в початковій школі; запропонувати орієнтовні мовні завдання для роботи з віммельбухами на початковому ступені вивчення англійської мови. У статті використано такі методи дослідження, як аналіз, синтез, систематизація, узагальнення, які допомогли проникнути в сутність окресленої проблеми. 3'ясовано, що Нова українська школа покликана виховати всебічно розвинену, соціально активну особистість, яка вміє ухвалювати відповідальні рішення, дотримується прав людини та вільно долає мовні бар'єри в міжкультурній комунікації. Для цього сучасні уроки англійської мови треба будувати так, щоб вони створювали умови для спілкування (складання учнями монологів, діалогів, полілогів на різні теми 3 різною метою). Цій меті і підпорядкований ілюстративний матеріал віммельбухів. У статті запропоновано мовні вправи, які допомагають учням навчитися висловлювати свої думки правильно, послідовно, точно і виразно; спонукають їх до безпосередніх висловлювань, заохочують до складання розповіді, придумування своїх початків і фіналів оповідань. Крім того, під час організації такого спілкування і навчання значну увагу приділено розвиткові навичок культури мовлення, що сприяє підвищенню мовленнєвої культури учнів і формуванню в них навичок комунікативної діяльності в будь-якій сфері життя.

Ключові слова: віммельбух, культура мовлення, мовний бар'єр, міжкультурна комунікація, Нова українська школа, реформа початкової освіти. 